\title{
Roman and Runic in the Anglo-Saxon Inscriptions at Monte Sant'Angelo: A Sociolinguistic Approach
}

\author{
Michelle Waldispühl (University of Gothenburg)
}

\begin{abstract}
This paper addresses the Anglo-Saxon personal name inscriptions at Monte Sant' Angelo in Southern Italy from a sociolinguistic angle. The main interest lies in the mix between Roman and runic writing and its interpretation in the light of individual literacy and the cultural context of medieval pilgrimage. Four from a total of five inscriptions were written in runes; two of these show significant influence from Anglo-Saxon scribal practices and Roman epigraphic writing. The fifth Anglo-Saxon name is written entirely in Roman letters. Drawing on theoretical approaches from modern sociolinguistic studies of multilingualism in writing, this study suggests that the use of mixed Roman-runic practices reflects the biscriptal background of the respective carvers and was applied in situ to individualize the inscriptions. However, not all the inscriptions show such a mix; hence either skill or personal preference varied among the pilgrims. The practice of mixing evident in the runic inscriptions does not fully correspond to previously described features of multilingual and multiscriptal writing, which is why a new term, "heterographia", has been coined in this study to include mixing not only in a language and a writing system, but also on a graphetic and orthographic level. Finally, the use of runes or Roman script for one's personal name is interpreted as an expression of social identity dependent on the person's social embedding.
\end{abstract}

Keywords: Anglo-Saxon runic inscriptions, medieval graffiti, sociolinguistics of writing, multilingual writing, language contact, personal names, identity, medieval pilgrimage

Tn the course of different migration processes in the Middle Ages, runic literates traveled south, west and east and left written traces at places

\footnotetext{
Waldispühl, Michelle. "Roman and Runic in the Anglo-Saxon Inscriptions at Monte Sant'Angelo: A Sociolinguistic Approach."

Futhark: International fournal of Runic Studies 9-10 (2018-2019): 135-158. DOI: $10.33063 /$ diva-402192
} 
abroad. There are within this heterogeneous group of inscriptions ten instances in Italy which form a subgroup from one particular historical context: between A.D. c. 650 and 850, Anglo-Saxon Christians, probably pilgrims, traveled to Rome and Jerusalem and along the way they inscribed their names on the walls of the Roman catacombs of Commodilla, St Marcellinus, St Peter and St Pamphilus and at the Sanctuary of San Michele in Monte Sant'Angelo (Gargano).

These graffiti were first discovered by the Italian epigraphist Carlo Carletti (Carletti 1980, 1984-85) and thereafter presented largely separately in different publications (Mastrelli 1980; Arcamone 1981, 1992; Derolez and Schwab 1983, 1994). Ray Page remarks on some of the inscriptions in his Introduction to English Runes (1999), and Maria Giovanna Arcamone (2007) subsequently presents an overview of all the interpretable inscriptions, including pictures and a description of the epigraphic, runographic and etymological characteristics of the inscribed personal names. The most recent find in the catacombs of Pamphilus in Rome is presented by Luisa Izzi (2014, 147 and n. 28) and "possibly read as ' $[++]$ CYNRIC'”. The period to which the inscriptions are historically dated begins with the conversion of the Anglo-Saxons in the beginning of the 600s, and from 650 there are accounts of Anglo-Saxon pilgrims to mainland Europe. The terminus ante quem, on the other hand, is determined by the alleged Saracen attack of the sanctuary after which the place was abandoned (cf. Foxhall Forbes 2019, 178 f.).

In her article, Arcamone $(2007,128,137)$ points out that the pilgrims not only knew how to carve runes but, as Christians, must also have mastered the Roman alphabet. On the walls of the Sanctuary of San Michele and in the Roman catacombs there is further evidence for this assumption since we find Anglo-Saxon names written not only in runes but also in Roman letters (Arcamone 2007, 128; Carletti 1984-85, 2002). Page also (1994, 182; 1999, 224) mentioned the inscriptions' connection to Roman alphabetic literacy and a possible learned background of the Anglo-Saxon pilgrims in Italy but did not delve deeper into the matter. Thus, previous runological research had no systematic focus on the effect Roman writing and the social and situational context of pilgrimage might have had on the runic inscriptions far away from the "runic homelands".

In this paper, I address such Roman-runic "contact effects" in the inscriptions of the Anglo-Saxon pilgrims but limit my study here to the inscriptions at the Sanctuary of San Michele. ${ }^{1}$ My main aim is to con-

${ }^{1}$ On the Anglo-Saxon inscriptions in Rome, see most recently Insley (2008) and Izzi (2014). 
tribute to the hitherto neglected social contextualization of the graffiti, examining the literate skills of the writing pilgrims and possible social meanings of the inscriptions by taking a sociolinguistic approach. In a recent paper, Helen Foxhall Forbes $(2019,170)$ also points out that the main focus of scholarly research has so far been on the philological and onomastic features of the inscriptions while spiritual and social aspects have not been sufficiently addressed. Forbes focuses her study on the situational and contextual embedding of the graffiti on the walls at Monte Sant'Angelo and seeks to explore their significance for issues of devotion and identity with a historical and theological approach (see below).

In my analysis, I follow the method applied in modern sociolinguistic studies of writing systems in contact and include visual, material and linguistic characteristics of writing (cf. Sebba 2012, 102-06), the first concerning such matters as spatial arrangement, layout and script style; the second technical execution. Given that the Anglo-Saxon inscriptions in Italy appear only as single, syntactically isolated names, the linguistic analysis will only touch on orthography. Mark Sebba's studies have shown not only that visual aspects in particular are often neglected in research on multilingual texts (Sebba 2012, 102) but also that such features can serve a sociolinguistic function, such as underlining equality, for example, or expressing a certain identity or ideology (Sebba 2009, 39 f.; 2012, 109).

In the following, I will first present the historical and local context of the Anglo-Saxon inscriptions at Monte Sant'Angelo in Gargano. The effects of contact will then be separately addressed for each inscription in the section "Roman and runic writing in the Anglo-Saxon names". In the subsequent sections, sociolinguistic explanations for the use and choice of script will be discussed in the light of modern theories of multilingual language use and with respect to the historical and local context.

\section{Historical context}

\section{Anglo-Saxons in Italy}

Pilgrimages were extremely popular among medieval Christians, and both clerics and laypeople undertook journeys to the Holy Lands or other places of great religious significance (cf. e.g. Webb 1999). The AngloSaxon pilgrims who visited Monte Sant'Angelo most likely continued their journey to Jerusalem by boat from ports close to Gargano (Sinisi 2014, 47, 59 f.). Their pilgrimage was probably religionis causa, i.e. undertaken in order to find "a closer link with the divinity in order to reach a 
state of perfection of the soul". The function of the pilgrims' graffiti should certainly be seen in this religious context as having spiritual, devotional and commemorative purpose. The names may represent either a kind of ratification of "a pact with God that they had come all that way to sign" (p. 60 ) or, more likely, may be compared with medieval memorial practices known from Libri vitae, where people left their name to represent their souls, to be prayed for and commemorated during their lifetime and in the afterlife (cf. also Foxhall Forbes 2019, 188-92).

There is no historical data on the Anglo-Saxon pilgrims in Gargano in particular (cf. Handley 2013, 759-61) and hence we do not know who the persons behind the names investigated in this article were, whether they were clerics or laypeople, what exactly their motivations for the pilgrimage were or whether they were traveling in a group or on their own. It is moreover unclear whether the names indicate the pilgrims themselves or those close to them (p. 747). According to Carletti (2002, 354), the large number of Anglo-Saxon name graffiti in uncial writing in the catacombs of Rome points to a learned and clerical background for the writers. It might, however, be reasonably assumed that the group of people traveling to Italy was a heterogeneous one, as their level of literacy may also have been.

\section{Literacy in Anglo-Saxon England}

When Christian Latin literacy was introduced in Anglo-Saxon England in the 500s, it "did not spring up in a scriptless desert" (Derolez 1990, 400). Runic writing was found at that time, although evidence is scarce (Barnes 2012, 42 f.; Page 1999, 25), and the Anglo-Saxons presumably already had knowledge of the Roman script from previous contacts with the Continent (Page 1999, 213) and from Latin inscriptions from Roman colonial times still present in the Anglo-Saxon linguistic landscape.

The epigraphic and manuscript evidence of Anglo-Saxon England strongly suggests that runes and Roman script existed contemporaneously from early on and for a long period. Much Anglo-Saxon runic writing is mixed or interwoven with Roman script and Latin (cf. most recently Okasha 2018). Objects variously occur with inscriptions in both scripts, runic and Roman, and both languages, vernacular and Latin, side by side (see below); alternatively, occasional single runes occur in Roman inscriptions and manuscript texts (cf. Page 1999, 213-24, and Okasha 2018 for examples).

As concerns the functional distribution of the runic and Roman writing systems in Anglo-Saxon England, the Roman alphabet was used more 
frequently than the runic one in both epigraphic and manuscript writing. In manuscripts, runes are - apart from the characters $P$ and $P$ which were borrowed into insular script - clearly less common than Roman letters. The two writing systems seem otherwise to have enjoyed a comparable status since they occur in similar contexts, although, in general, Latin texts appear in Roman script rather than runic whereas both scripts were used for Old English (Orton 2014, 231 f.; Okasha 2018, 35). For personal names, a socially coded distribution can be noted on East Anglian coins from the 700s where names of royals were written in the Roman alphabet whereas names of officials or moneyers appear in runes (Page 2003, 551). Regarding the epigraphic use of the two writing systems, Parsons (1994, $110 \mathrm{f}$.) shows that their spatial distribution is very similar. The evidence clearly indicates that active knowledge of both Roman and runic writing systems existed contemporaneously (Okasha 2018, 35).

Of the total of around 350 inscriptions from Anglo-Saxon England, seventeen inscriptions dating from the 700 s to the 800 s contain both runic and Roman writing according to Elisabeth Okasha $(2018,31 \mathrm{f}$., 34, $41 \mathrm{f}$.), who lists them and classifies them into four groups. The first group comprises Roman-script texts with occasional single runes (e.g. the Chester-le-Street stone with the personal name EADmVnD); the second only comprises the Franks casket, the texts are runic but for one in Roman script; the third shows parallel inscriptions in both scripts (e.g. the Falstone stone, see below); the fourth contains different texts in each script (e.g. the Hackness stone with a prayer in Latin written in Roman script and a now indecipherable runic inscription and a text in runic ciphers).

On a syntactic level, the two scripts are kept apart and not mixed. Parallel inscriptions where the same text appears in Roman and runic on the same object provide particular evidence for this practice. An example is the Falstone stone with an Old English memorial formula *æftæ. . . becun $* f$. . . gebidædpe $*$ saule in runes and . . ITA. . .AEFT*R HROETHBERHT* BECUNAEF... EOMAE3EBIDAEDDERSAULE in insular majuscules, the translation being '(NN set up) a monument after Hroethberht after his uncle. Pray for his soul' (cf. Page 1999, 142, transliteration according to RuneS-DB). Okasha explains this parallel use of scripts as "artistic, to exhibit knowledge" (Okasha 1971, 72; cf. also 2018, 40). Christine Fell $(1994,129)$ suggests two further explanations, of which the first is "to reach as wide an audience as possible and present your text for all who are literate in either script", which corresponds to sociolinguistic considerations on modern parallel script use (cf. Sebba 2012, $109,112)$. Okasha $(2018,39)$ considers this explanation unlikely, however, 
since the Anglo-Saxon context makes a reader capable of reading only one script improbable. Fell's second explanation, that the multiscriptal practice for epitaphs might be a reference to Christ's inscription on the cross, which according to the Gospel of St Luke 23:38 was written in letters of Greek, Latin and Hebrew is more far-fetched and fairly unlikely. Rather, I consider this use of parallel script might be linked to aspects of local identity (see section "Script choice and identity in personal names" below). As noted above, recent sociolinguistic research has shown that different scripts can express such features and thus, as regards choice and use of writing systems, it is not only readability which is significant (Sebba 2009, 39 f.; 2012, 109).

\section{Local context of the inscriptions at Monte Sant'Angelo}

The runic inscriptions at Monte Sant'Angelo in Gargano in Southern Italy are situated in the cave-sanctuary of San Michele, a sacred Christian place where the Michaelian Cult has been practiced since the sixth century (Sinisi 2014, 51). It is a place of religious importance and spiritual power to which pilgrims have traveled since the beginnings of Christianity in Europe.

In 1949, when the sanctuary was renovated after an earthquake, a late antique chapel with a long porticus to the sanctuary was rediscovered (cf. Arcamone 2007, 129). ${ }^{2}$ On its walls were found around two hundred medieval graffiti carved by pilgrims. These walls comprise several historical layers of inscriptions accidentally brought together. The graffiti are mainly personal name inscriptions, but symbols such as the signum crucis and short prayers can also be found (cf. Carletti 1980; Foxhall Forbes 2019, 184). Among these inscriptions are, as mentioned above, five interpretable Anglo-Saxon name graffiti, one in the Roman alphabet and four in the Anglo-Saxon futhorc. Four of these carvings were discovered in 1976 when the inscriptions in the late antique porticus leading to the sanctuary were systematically investigated (Carletti and Otranto 1980), and the fifth, leofwini, was added to the corpus after a subsequent examination by Maria Giovanna Arcamone (1992). According to Derolez and Schwab (1983, 114 f.), a further runic inscription can be detected, but due to erosion and overwriting it can barely be deciphered, much less interpreted. Three runic inscriptions are located on the western façade of the wall at the entrance

${ }^{2}$ For the topographical context and a reconstruction of the late antique building, see the excellent digital images by Massimo Limoncelli in Foxhall Forbes $(2019,171-77)$.

Futhark 9-10 (2018-2019) 
to the long porticus, hereberehct, herræd and wigfus, in addition to the uninterpretable runic scratches. The fourth inscription, leofwini, is located on a column inside the porticus, as is the Anglo-Saxon name EADRHID in Roman script. ${ }^{3}$ Since four of the inscriptions are grouped closely together, three of them on the same ashlar, it may be assumed that they were inscribed on the same occasion (cf. Derolez and Schwab 1983, 113) and they may even be interpreted as belonging to pilgrims who had traveled in a group. This conclusion is, however, only tentative. As already mentioned, we lack historical data about these Anglo-Saxon pilgrims, and it was moreover not uncommon to inscribe names of relatives, i.e. people who were not present.

\section{Runic and Roman writing in the Anglo-Saxon names}

\section{Bind-runes and hc-spelling in Hereberehct}

The inscription of the name Hereberehct is clearly visible and can be found at the main entrance to the gallery on the wall on the right side (see fig. 1). The individual runes are 4.2 to $5.2 \mathrm{~cm}$ high (cf. Derolez and Schwab 1983, 117) and the inscription can be read as FMMBMRMN $\uparrow$ hereberehct Hereberehct. This renders a common Anglo-Saxon male name with here$<$ Germanic *harja- as the first element and -berehct < *bertha- (with an epenthetic vowel) as the second. The technical execution with deep and neat carvings bears witness to an experienced carver (cf. also Arcamone 2007, 131).

The inscription shows a sophisticated and rather unusual use of bind-runes. There are three consecutive instances of $M$ as the first element: MB, M , MA, and word-initially we even find the tri-partite bindrune FR. According to Mindy MacLeod (2002, 81, 94), the bind-runes found in runic inscriptions in Anglo-Saxon England nearly all appear in a context connected to an ecclesiastical environment. This fact is particularly highlighted in the only other example of a triple bind-rune in an intelligible text: The inscription on the Whitby comb, an inscription dated to the late 600 s or early 700 s is read as dæusmæus:godaluwalu dahelipæcy... Dæus mæus God aluwaluda helipæ Cy... (cf. Waxenberger 2011, $74 \mathrm{f}$.) and interpreted by Bammesberger (2010) as 'deus meus,

\footnotetext{
${ }^{3}$ For an illustrative overview of the location of the inscriptions in the porticus see Derolez and Schwab (1983, fig. 6) and Foxhall Forbes (2019, fig. 8 and fig. 13). The leofwini inscription is correctly located in Trotta $(2012,104,108$ f.; cf. also Foxhall Forbes 2019, 183).
}

Futhark 9-10 (2018-2019) 


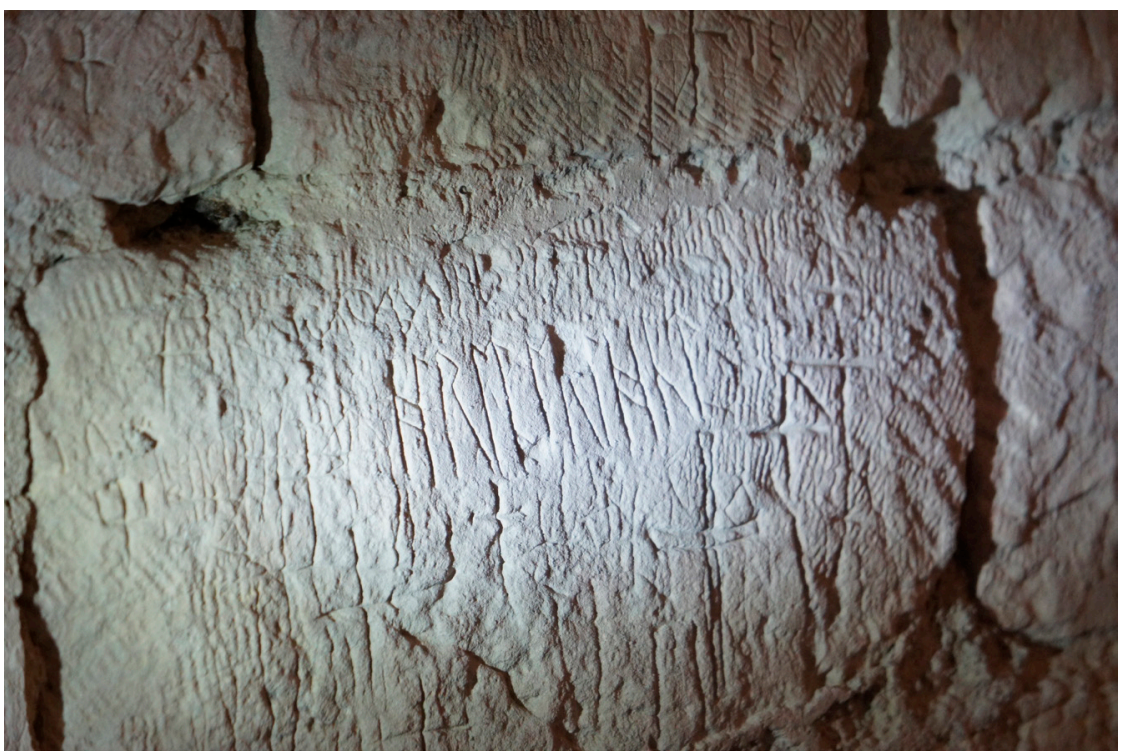

Fig. 1. The hereberehct inscription. Photo by the author.

may God the Allruler help Cy-[' or 'deus meus, O God Allruler may you help Cy-' (cf. also Page 1999, $164 \mathrm{f}$.) where $C y$-is assumed to be the first part of a personal name. The inscription is partly in Latin and contains a formulaic prayer. Hence, the use of bind-runes in Anglo-Saxon England suggests that the writer of the hereberehct inscription belonged to a Latin-speaking milieu. Two new finds with multipartite bind-runes in the inscriptions on the Shropham lead tablet (not yet dated) and the Ipswich belt buckle (dated to the 700s; cf. Waxenberger 2016) further indicate that the use of multipartite bind-runes might have been specific to the regions of Northumbria and Mercia. ${ }^{4}$

The hereberehct inscription, with its extensive use of bind-runes, suggests their use as a stylistic feature perhaps linked to the functional context in which the inscription was embedded. Together with its prominent

\footnotetext{
${ }^{4}$ I thank one of the peer reviewers for pointing this out to me. Both inscriptions are, however, difficult to read and have not yet been properly interpreted (cf. Waxenberger 2016).

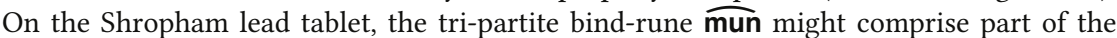
second element - mund in a male name. This inscription might alternatively be written in the younger Scandinavian futhark, however, and be too late in date to be of interest here (p. 369). Further investigations are needed to provide a more solid basis for secure comparisons.
} 
placement on the western façade of the hall leading to the porticus and the tidy execution of relatively large runes, bind-runes could have served to highlight visually and emphasize the inscription at this particular sacred place.

One feature that points to the influence of scribal practices is the spelling Nh hc in the second name element -berehct. The spelling of the Germanic velar fricative $[\chi]$ in both initial and medial position in Old English runic inscriptions is exclusively $\mathbb{A}$ (cf. Derolez and Schwab 1983, 121). The digraphic <ch>-spelling, however, occurs in Old English texts written in the Roman alphabet, but even here the single-graph spellings $<\mathrm{c}>$ and $<\mathrm{h}>$ are common. ${ }^{5}$ Less frequently, $<$ hc $>$ (and $<$ gh $>$ ) also occur (cf. Seiler 2014, 163). The spelling hc should not in any case be deemed a mistake as Arcamone $(2007,131)$ suggests but a spelling variant. Interestingly, in Seiler's $(2014,150)$ study of early Old English spelling, the variant <hc> was found only in Kentish and Mercian texts dated between 750 and 775 . Due to the lack of comparative material, this data is insufficient to date the hereberehct inscription or indicate the writer's origin. Nevertheless, it is remarkable that both spelling practice and use of bind-runes can be linked to Roman script practices in Anglo-Saxon records dating to the $700 \mathrm{~s}$ and located in the south of Northumbria, Mercia and Kent. These two features surely indicate that the carver was familiar with vernacular scribal practices in Roman script (cf. also Derolez and Schwab 1983, 122; Page 1994, 182).

\section{Serifs and double spelling in Herræd}

The herræd inscription is also placed on the west façade of the entrance hall leading to the long porticus, more specifically on the right capital supporting the entrance arch. The characters are on average c. $1.7 \mathrm{~cm}$ high (cf. Derolez and Schwab 1983, 116). The carvings are technically tidy and were probably executed by an experienced scribe (see fig. 2). A frame around the entire inscription was used as a graphic element to outline the runes. It marks the writing space, possibly adding visual emphasis to the inscription after the runic characters were carved. The reading of the inscription is AMRRFW herræd Herræd, and thus it also renders a male name. The first name element is the same as in Hereberehct, her- < *harja-, but with no linking vowel $-e$-, and the second element is $-r æ d<{ }^{*} r a \bar{d} d i-$.

${ }^{5}$ Compare for example HROETHBERHT* in Roman capitals on the Falstone stone mentioned above. 


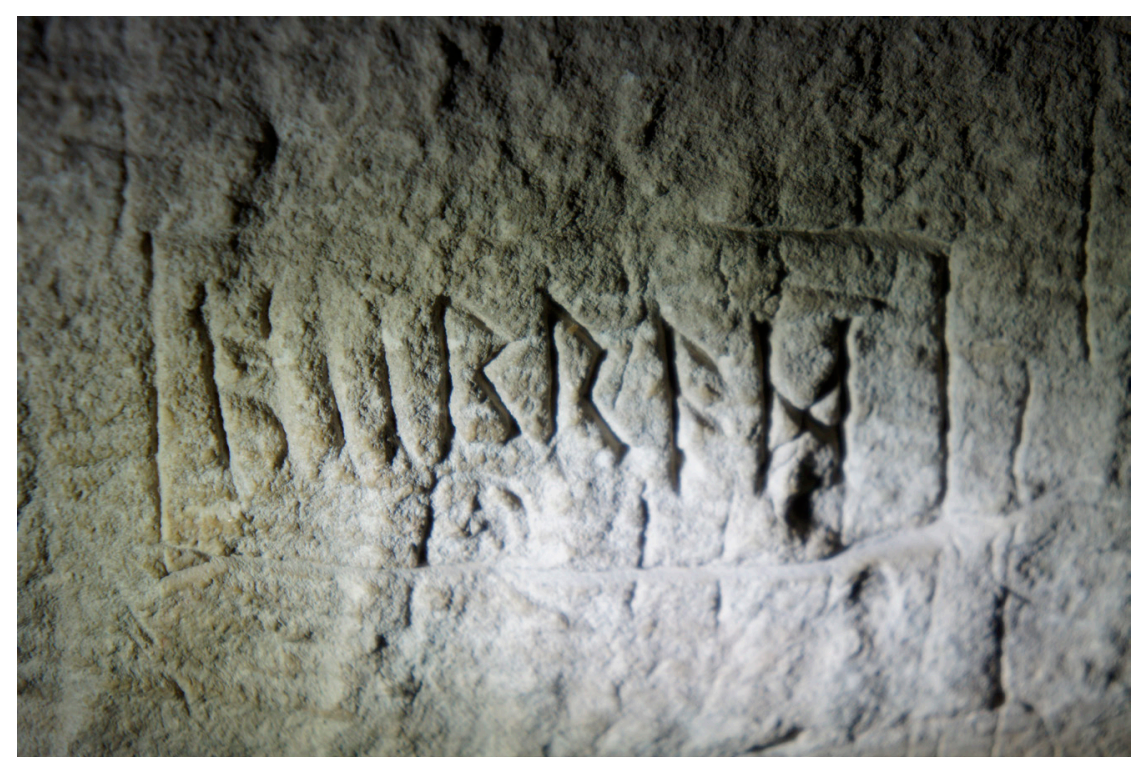

Fig. 2. The herræd inscription. Photo by the author.

Even though this inscription makes no use of bind-runes, which has been shown to be related to familiarity with Roman writing, it does exhibit two other features prominent in Roman writing: serifs and double spelling. Serifs are not limited exclusively to Roman alphabet writing in Anglo-Saxon England; they do occur in runic inscriptions. According to Page (1999, 103), however, the practice was transferred from monumental Roman writing to monumental runic writing. He therefore assumes that the rune-carvers who employed serifs also produced Roman inscriptions, and that they were responsible for the transfer of this graphic feature to runic epigraphy. Three Anglo-Saxon examples of runic inscriptions with serifs further suggest the connection of this practice to a biscriptal milieu since they occur in combination with serifed Roman script inscriptions on the same object (Hartlepool I, Lindisfarne I, Monkwearmouth II). It cannot be determined whether the serifs were applied to the herræd inscription ad hoc or whether they were an established trait of runic epigraphy; with this stylized graphic feature, however, the herræd carver in Italy visually highlighted the inscription, in addition to employing a frame, as mentioned above.

The second feature, double spelling, is clearly influenced by Roman writing practices although not unusual in Old English runic inscriptions. 
In his investigation of Anglo-Saxon runic inscriptions from 1962, which to my knowledge is still the most recent on the subject, Ray Page considered whether the "runic practice" of avoiding double runes could in fact be regarded as a general runic spelling rule or instead only applied to certain local runic corpora. In his thorough account of Anglo-Saxon runic inscriptions featuring either double runes or single runes where vernacular Roman writing would expect double spelling, he demonstrated that a significantly high number of inscriptions with double runes derived from mixed Roman-runic writing contexts and might have been influenced by non-runic spelling, such as unneg on the Franks casket or fearran on the Ruthwell cross, both objects with runic and Roman texts (cf. Page 1962, 900-02; additionally, $<\mathrm{g}>$ for $[\chi]$ in unneg can be interpreted as a Roman spelling occurring in manuscripts, cf. Parsons 1994, 98 f.). Other sequences with double runes render Latin words or names (e.g. ... ohann...s Iohannis on St Cuthbert's coffin) and can likewise clearly be linked to Latin and Old English scribal spelling practices. The instances showing single spelling where in contrast double spelling in manuscript texts would be expected are, according to Page (1962, 902), not proof of a runic spelling rule since even these cases find parallels in non-runic texts. Lastly, even the unconventional spelling of long vowels with double runes in riicnæ (Ruthwell) and liin (Brunswick) can be paralleled in manuscript texts, for example in the Lindisfarne Gospels and the Durham Ritual (cf. Page 1962, 903). Although some forms remain unexplained (e.g. hilddigyp, Hartlepool II), it can generally be concluded that the use of double runes was probably influenced by Roman script and associated scribal practices. This context might indicate that the herræd carver was familiar with scribal spelling practices, as was the hereberehct carver. The double spelling in herræd marking the end of the first name element and the beginning of the second also occurs in Old English manuscript sources (Searle 1897, $294 \mathrm{f}$.).

The runic spelling $\mid \mathrm{f} æ$ for the Old English sound resulting from fronting and $i$-mutation $\left(<\right.$ Germanic $\left.{ }^{*} \bar{e}_{1}\right)$ in -ræd indicates that the inscription is not a transliteration of the name in Roman script, but rather that the carver (also) followed runic spelling conventions.

\section{Wigfus and Leofwini}

The remaining two interpretable runic inscriptions show no remarkable characteristics with respect to script mixing. The wigfus inscription is located on the same ashlar as herræd. The single characters are clearly 


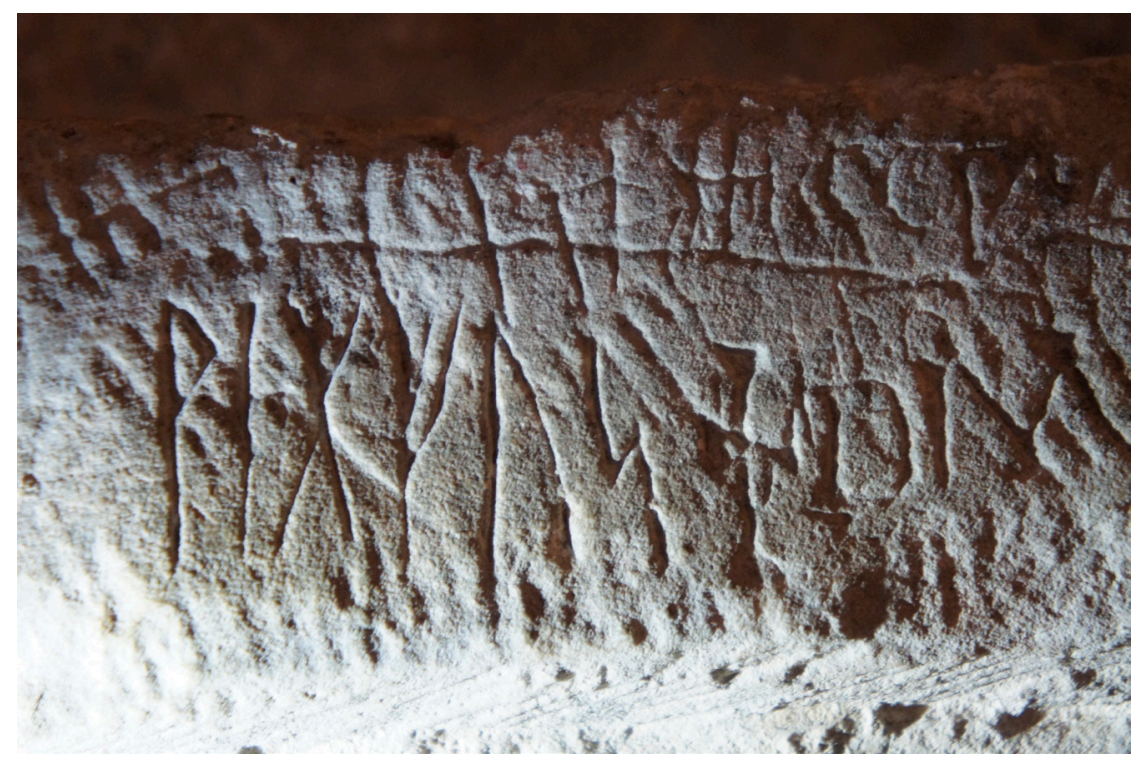

Fig. 3. The wigfus inscription. Photo by the author.

visible, $2.5 \mathrm{~cm}$ high and neatly executed (cf. Arcamone 2007, 134; see fig. 3). The reading is PIXY $\ 4$ wigfus which can be interpreted as a dithematic male name composed of the elements wig- $<{ }^{*}$ wiga- and $-f u s<{ }^{*}$ funsa-. A signum crucis with serifs is carved after the final s-rune, but it is not possible to identify whether the cross and the runic inscription correspond visually in terms of carving technique. An inscription in uncials follows the signum and it could just as easily belong to this inscription. It is, however, not unlikely that the signum was executed independently of both inscriptions since this symbol appears all over the walls.

The leofwini inscription, finally, is notable among the runic inscriptions because it is placed on a column inside the long porticus, has very small characters ( $1 \mathrm{~cm}$ high) and is less tidily executed. The single carvings have frayed edges and the characters are not aligned horizontally but curve downwards towards the end of the inscription. The round surface of the column was obviously more difficult to inscribe than the plain wall of the entrance hall. Nevertheless, the inscription gives the impression of having been executed by a scribe less experienced than those already discussed. The inscription's reading, however, is not impeded. It is TMFYPI+I leofwini and renders the dithematic male name Leof wini with the common name elements leof- < ${ }^{*}$ leuba- and -wini $<{ }^{*}$ wini-(cf. Arcamone 2007, 133). 


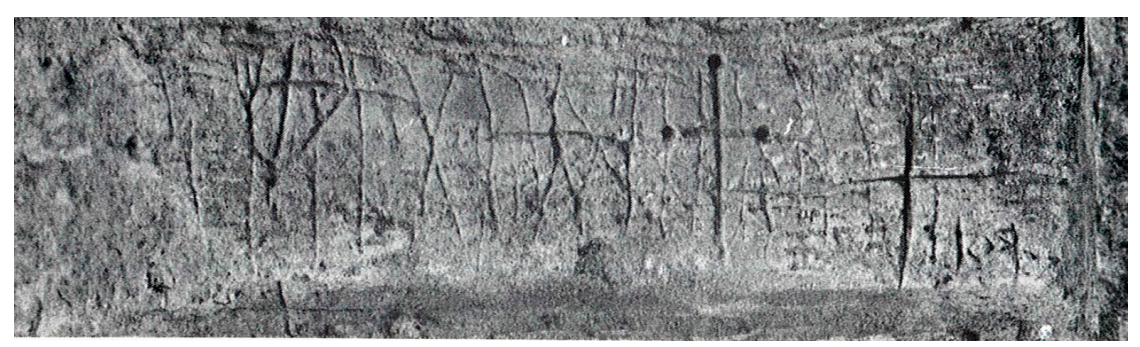

Fig. 4. The uninterpretable runic inscription (Derolez and Schwab 1983, fig. 7B)

\section{Uninterpretable inscription in runes}

On the capital on the western façade of the entrance hall, directly below the wigfus inscription, is one more carving featuring runic characters. They are difficult to decipher, partly due to scratches and erosion, and partly due to overlap with overlaid inscriptions. Additionally, the runes have not been as tidily executed as the other inscriptions on the same wall. Derolez and Schwab (1983, 115, 124; cf. fig. 4) tentatively read s mægu or s mægy but offered no interpretation. This reading, however, requires reexamination since what was taken by Derolez and Schwab to be the lower stave of the $æ$-rune in fact seems to be a longer, shallower line belonging to the circled cross inscription carved over the $m$-rune. Furthermore, a $d$-rune following $\mathbf{u}$-which Derolez and Schwab also noted but did not include in their final reading - can be deciphered and positively identified. The reading should additionally include a clearer indication of the characters of which traces can be detected, even if they cannot be deciphered. This pertains to remnants of at least two likely characters following $\mathbf{d}$.

Due to the current condition of the graffiti, it is hard to judge whether this carving originally comprised an intelligible runic text or was instead a rune-like imitation by a non-literate scribe. In any case, however, it certainly shows no mixed-writing features.

\section{EADRHID: an Anglo-Saxon name in Roman script}

Further Germanic names can be found on the walls at Monte Sant'Angelo, but only one can clearly be assigned Anglo-Saxon origin (cf. Sinisi 2014, 43). This last legible inscription of an Anglo-Saxon name is entirely in Roman script. It is placed inside the gallery on the so-called rulers' pillar on the left-hand side of the scala tortuosa, one of the staircases leading from the gallery to the sanctuary. The inscription begins with a cross and reads: 


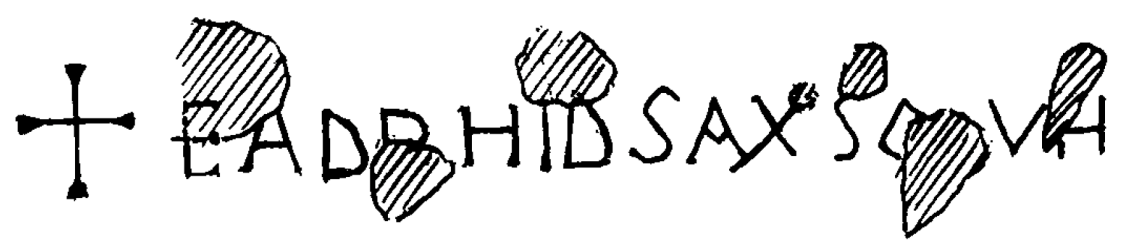

Fig. 5. The Eadrhid inscription (Derolez and Schwab 1983, 125, fig. 12)

+ EADRHID SAXSO V(IR) H(ONESTUS) (cf. Derolez and Schwab 1983, 125 f.; see fig. 5). ${ }^{6}$ Eadrhid has been interpreted as a male name comprised of the elements ead-< ${ }^{*}$ aud-and -rhid $<{ }^{*}$-ræd < ${ }^{*}$ rädi-(cf. Arcamone 1980, 287). The obscure spelling of the second element is extensively discussed in Derolez and Schwab (1983, 127-30). They propose that the name is a "clumsy Langobardian rendering of OE Eadred" following the common $<$ h $>$-spelling of Langobardian names in -hari such as $<$ Bertarith $>$ or $<$ Perctharith $>$ for $<$ Perchthari $>$. However, this suggestion fails to explain the <rhid>-spelling since the Langobardian spellings referred to in Derolez and Schwab concern $<$ th $>$-spellings as a variant of $<\mathrm{t}>$-spellings. More convincing, especially in regard of the fact that an autograph is less likely than a copy executed by a professional carver (see below), is their second suggestion "that the carver was presented with a model in insular script, and that he misinterpreted e.g. Eadfrid written <eudfnıd> producing EADRHID”.

This inscription is remarkable for several reasons. According to Derolez and Schwab (1983, 105), its placement just below three commemorative Latin inscriptions naming the renowned Langobardian rulers Grimuald, Romuald and Gunperga suggests that the Anglo-Saxon Eadrhid had some relationship with the ruling Langobardian family. Such a connection between Anglo-Saxons and Langobards is probable in light of the historical context since Cunincpert, the Langobardian king from 688 to 700, was married to Hermelinda "ex Saxonum Anglorum genere" (cf. Derolez and Schwab 1983, 109).

\footnotetext{
${ }^{6}$ Arcamone $(2007,130,149)$ gives the original but wrong reading, EADRIHD, and in addition the incorrect drawing from Carletti (1980, 72, no. 56), although she had corrected the reading of the second name element to RHID in one of her earlier publications, referring to Carletti's plate 13 (Arcamone 1981, 167 and n. 34). Derolez and Schwab (1983, 125) confirmed the reading EADRHID after reexamination of the inscription. See also Carletti $(2004,526)$ for the correct reading.
} 
Additionally, the technically professional execution of the inscription makes it stand out among other carvings in the same area (e.g. Carletti 1980 's numbers 50, 51, 53, 54). Derolez and Schwab $(1983,107)$ therefore consider that it may have been the work of a professional carver rather than an autograph, something that would indicate the higher social status of Eadrhid.

Carved in addition to Eadrhid's name are the epithets SAXSO 'Saxon' and the abbreviation $\mathrm{V} \mathrm{H}, v$ (ir) h(onestus) - an honorific title "used by laymen of middling to high status" in Langobard Italy (Handley 2013, 747). The latter attribute together with the spatial and technical context of Eadrhid's inscription serve to explain why Roman script was used for this inscription rather than runes. Eadrhid might have been an Anglo-Saxon living abroad and thus acquainted with Latin customs. It is on the other hand remarkable that the appellation SAXSO was added to the name as a lexical marker of origin and ethnicity.

This inscription shows no spatial correspondence to the runic inscriptions in the entrance hall and also stands out among the inscriptions with Anglo-Saxon names in its use of Roman script. Nevertheless, a graphic correspondence can be found in the letters showing the same type of triangular-shaped serifs as in the runic herræd inscription. The assumption that Eadrhid's inscription was made by a professional carver strengthens the argument that this graphic feature might have been applied to the runic inscription in order to stylize and highlight it and to make it appear "elegant".

\section{Roman and runic practices intertwined: "heterographia" and individual style}

The analyses in the preceding section have uncovered various forms of parallels and entanglement of runic and Roman writing in the AngloSaxon pilgrims' inscriptions at Monte Sant'Angelo. First, both writing systems were used to render Anglo-Saxon personal names at the same sacred Christian place. Second, graphic features (serifs in herræd) and spelling practices (hc-spelling in hereberehct and double-spelling in herræd) were transferred from epigraphic or scribal practices in Roman letters to runic writing. Additionally, the extensive use of bind-runes in the hereberehct inscription has been interpreted as the influence of a Latin-speaking milieu even though it is not directly linked to Roman alphabet writing practice. There are, however, also runic inscriptions 
showing no Roman script influence. In view of the kind of mixed-writing inscriptions found in the Anglo-Saxon homelands (see the subsection "Literacy in Anglo-Saxon England" above), it is furthermore remarkable that no parallel inscriptions with the same name recorded in both writing systems occur at Monte Sant'Angelo. Moreover, the letter inventories of the two writing systems were strictly separated, i.e. changes of script or hybrid letter forms within one inscription do not occur.

Seen in the light of the sociolinguistic theoretical frameworks established in studies on modern writing systems in contact, these results cause certain problems. The writing conventions of the historical material discussed here cannot be seamlessly embedded into previous models. Mark Sebba's (2012) model of multilingualism in written discourse concerns multilingual texts, i.e. texts using more than one language, and his analytical focus relates to the visual and grammatical mixing of languages in a text. The former refers to the space occupied by texts written in the respective languages while the latter focuses on the content. A "mixing type" according to Sebba's understanding implies that a visual unit, e.g. a paragraph, contains text in two languages or that two languages are used within a grammatical unit, i.e. a sentence. Consequently, the Roman-runic practices of Monte Sant'Angelo do not correspond to Sebba's (pp. $107 \mathrm{f}$.) category of "mixing type" in multilingual writing, since his analytical starting point are texts or parts thereof in different languages. An analytical framework which is more applicable to the data is provided by Philipp Sebastian Angermeyer's (2012) study of Russian-American writing which discusses script choice in "digraphic usage", i.e. "the use of more than one writing system for the same language and by the same speech community" (p. 255). ${ }^{7}$ For such a context of writing systems in contact he delineates the categories "script alternation" (alternating code-switching of languages and script in one and the same text), "transliteration" and "script hybridity". These terms still do not fully describe the situation relating to the inscriptions considered here, however. Script alternation and transliteration occurred in England and constitute a characteristic of Anglo-Saxon literacy. But neither practice is found in the Italian inscriptions. Lastly, Angermeyer's

\footnotetext{
${ }^{7}$ The term "digraphic" is, however, problematic since it is used in graphemics as a designation of a two-letter spelling, such as $<$ sh $>$ for $/ \int /$ in English or $<\mathrm{ch}>$ for $/$ ç/ in German. A more appropriate term for the literacy described by Angermeyer is "biscriptal". In Bunčič et al. (2016, 51-54), "biscriptal" is used as a cover term for "the simultaneous use of two (or more) writing systems (including different orthographies) for (varieties of) the same language". The term "digraphia" is also included, however, but restricted to specific types of biscriptality (pp. 56-59).
} 
(2012, 263) definition of "script hybridity" cannot be applied since it covers only instances of letters from two writing systems being mixed at the lexical level. As discussed here, however, the mixing in the Anglo-Saxon inscriptions in Italy is neither on the level of language nor alphabet, but rather on the level of different resources specific to written language: the graphic (serifs, perhaps also bind-runes) and orthographic (spelling practices) level. They integrate parts of originally Roman script traditions - both epigraphic and scribal - into runic writing. This type of mix is not mentioned in Daniel Bunčič, Sandra L. Libbert and Achim Rabus's (2016) comprehensive discussion of biscriptal writing either. Although they describe and define a wide range of sociolinguistically determined usages in biscriptal communities and contribute much to the field, they do not address the mixing of scripts on a textual, syntactical (called "graphic code-switching") or lexical level (pp. 69-71).

A parallel modern case for integrated spelling practices affected by foreign orthographies can, however, be found in modern German. In German magazines and texts deriving from computer-mediated sub-cultures, English graphemes are sometimes used, such as $<\mathrm{sh}>$ for German $<\mathrm{sch}>$ in e.g. <shatz $>$ and $<\mathrm{x}>$ for German $<$ chs $>$ in e.g. $<$ Abwexlung $>$ (cf. Androutsopoulos $2000 ; 2006)$. Just as with the case of digraphic H人instead of single $\mathrm{A}$-spelling in hereberehct, this linguistic integration is of course mediated by the same sound value of the respective variants in the two written languages. This feature of written use in German is based on an active knowledge of English and can more broadly be linked to the "heteroglossia in practice"-approach to multilingualism established in the context of late modern mobile and superdiverse societies (Blommaert and Rampton 2011). Within this approach, "meaning making is not confined to the use of languages as discrete, enumerable, bounded sets of linguistic resources ... Rather, signs are available for meaning making in communicative repertoires that extend across languages and varieties ..." (Blackledge, Creese and Kaur Takhi 2013, 192). Thus far, this sense of "heteroglossia" has mainly referred to spoken language but has not been confined to a particular medium. ${ }^{8}$ Written language use, however, also requires the consideration of visual semiotic resources and spelling, and the term "heteroglossia" can be modified to "heterographia" to clarify its

${ }^{8}$ The term is also independently introduced by Daniel Bunčič (in Bunčič et al. 2016, 62) where it is used for biscriptal situations allowing free individual choice of script, e.g. in Serbia where the Roman and Cyrillic alphabets exist alongside each other. Bunčič’s understanding of the term is different, however, and refers to the phenomenon whereby single scripts can flag varying meanings and can "speak with several 'voices"” in different situational usages. 
specificity to writing. Even though established to describe practices in late modern society, the definition just provided also applies to the use of written resources in the Anglo-Saxon inscriptions in Italy: graphic and orthographic resources of different languages and writing systems were utilized in the inscriptions according to the respective skill inventories, or personal preferences, of the different carvers.

Whereas the term "heterographia in practice" refers to the sociolinguistic situation and the way users of written languages apply linguistic resources to make meaning, the written product of such a practice, i.e. a word or a sentence showing characteristics of different linguistic repertoires, still remains undefined. I suggest broadening the terms coined by Angermeyer and Sebba to a more general "mixed writing" in order to include the mixing not only of languages and writing systems, but also of graphic features, orthography and other semiotic writing resources.

Such use of resources from two different writing traditions indubitably implies biscriptal competence among the carvers of runes in Italy. The question is, however, whether the heterographic use is an intended, individual act of the carvers of hereberehct and herræd, or whether the two systems were "momentarily blurred in their mind", as Angermeyer (2012, 263) suggests for the use of hybrid forms in his studies of biscriptal Russian-English speakers and writers in New York. The latter explanation cannot however be tested and the possibility must therefore remain open. It is of course not improbable that biscriptal writers used to writing with both scripts unconsciously mix resources from the respective systems. Yet a closer look at the visual presentation of both inscriptions rather suggests that the inscriptions were intentionally and creatively designed. The hereberehct inscription is comparatively large, clearly and visibly placed on the western façade of the entrance hall and carved deeply; herræd is framed and additionally visually emphasized by serifs. The two runic inscriptions lacking features linked to Roman script practices, on the other hand, show no visual highlighting. We can therefore assume that the carvers of hereberehct and herræd made intentional use of these resources for ostentatious stylistic purposes, possibly consciously with respect to the sacred location intended to eternally house their inscriptions.

\section{Script choice and identity in personal names}

The evidence of active knowledge of scribal practices among the AngloSaxon pilgrims in Italy raises one further question: why did they use runes at all? In the Sanctuary of San Michele they were surrounded by 
Roman inscriptions and as pilgrims in a foreign Christian context might be expected to use the script of the Roman church. Instead, they chose to use runes. In addressing this fact, Ray Page (1999, 224) tentatively assumed that "runes may have been a common script for giving one's name in an informal setting" and, alternatively, considered whether there "could ... be a distinctive usage here, Englishmen writing their signatures in what they regarded as a characteristically English script”. In an earlier publication, he suggested another alternative, namely a possible local variation within Anglo-Saxon England with "Northumbrians then as now advertising their distinctive culture" (Page 1994, 182).

In sociolinguistic research, choice-making in general (Coulmas 2013, 9) and script choice in particular are socially interpreted. Sebba (2009, 39-41) gives several examples of socially motivated script choices, e.g. as an identifier of religious culture (Urdu script as a marker of Muslim and Devanagari of Hindu culture respectively, see King 1998, 84, referred to in Sebba 2009, 39). Both Sebba and Angermeyer $(2012,269)$ state that writing systems or even different styles and graphic features within the same script can potentially function as an iconic and powerful symbol of the identity of certain language communities. As applied to the use of runes by Anglo-Saxon pilgrims, the results from studies on modern script choice support Page's second and consequently also third assumption. Runes might indeed have served as a symbolic marker of Anglo-Saxon or even Mercian or Northumbrian ethnicity, and they might even have been intended to stand out visually from the Roman inscriptions. Foxhall Forbes (2019, 201-03) arrives at a similar conclusion and stresses that the choice of runes should be seen as a deliberate act of expressing or performing ethnic identity. She makes the further interesting point that runes express social belonging and possibly also the pilgrims' shared acceptance of what English ethnicity might have meant; at the same time, as the only inscriptions on the walls of the porticus not written in Roman script, they consciously or otherwise mark the difference between their carvers and other pilgrims.

It is moreover not surprising that symbolic markers of identity occur in connection with personal names. Names serve as identifiers and individualizers of human beings as well as indicating social identity (cf. Aldrin 2016). This demarcation might have assumed particular importance in light of the memorial function of the names in the religious setting of the sanctuary (cf. the section "Historical context" above). On the other hand, I consider Page's initial suggestion that runes might have commonly served to render personal names in informal settings less probable for two 
main reasons: firstly, I doubt that the setting at Monte Sant'Angelo can be regarded as informal; the stylistic adaptions discussed in the previous section instead indicate that the setting contributed to a more formal execution of the names as skills allowed. Secondly, Eadrhid's inscription provides a counterexample to the use of runes for Anglo-Saxon names. Eadrhid's choice of Roman script, as noted above, is unsurprising against the background of his possible relationship to a Langobardian family. Interestingly, however, two symbolic markers of social identity were added to his name, $v$ (ir) h(onestus), giving his social status presumably within the Continental Langobardian community and the other, SAXSO, indicating his ethnic identity. Hence, this lexical marker fulfilled the same indexical social function as the runic writing system in the other inscriptions. This signifies that the marking of ethnic identity was considered important, even though it is unclear whether it was Eadrhid himself or the Langobardian community who decided to add this attribute. As regards the runic inscriptions, on the other hand, it is reasonable to assume that it was the pilgrims themselves who made the carvings.

\section{Conclusion}

The Anglo-Saxon runic inscriptions in Italy have fascinated scholars and attracted public interest ever since their discovery and their value for both historical and linguistic research certainly cannot be overestimated. While various aspects of their reading and structural linguistic interpretation as well as their broader historical context have been addressed in previous studies, the present paper has concentrated on sociolinguistic aspects of the use of runes for personal names in this specific context of Christian pilgrimage. The main focus concerned the mixing of writing practices from Roman script and runic traditions and its interpretation against the background of the pilgrims' literacy and social identity. The findings suggest that the choice of either runes or Roman script for Anglo-Saxon personal names in the Sanctuary of San Michele at Monte Sant'Angelo was based on the social context in which the pilgrim was embedded. Roman script was used only once, for a person with probable connections to the Langobardians. Runes seem otherwise to have been the primary writing system for Anglo-Saxons to have their names eternalized on the walls of the sacred place. The writing system may have functioned as a semiotic marker of ethnicity, parallel to the lexical indicator SAXSO added to the Anglo-Saxon name Eadrhid in Roman script. Nevertheless, two of four runic inscriptions show graphic and orthographic influences from epigraphic or scribal 
Roman script practices found in Anglo-Saxon England which on the one hand implies a biscriptal Roman-runic background for the respective carvers. On the other hand, they might have functioned as stylistic features displayed by the individual writers in order to highlight their inscriptions that moreover were visually emphasized through their technical execution and spatial placing. The other two runic inscriptions show none of these features of mixed writing or visual stylistics, however. Hence, these practices varied and were implemented on an individual basis dependent either on the respective carver's literacy resources or personal preference.

The term "heterographia" has been coined to describe the phenomenon of mixed writing practices in biscriptal use shown in two of the AngloSaxon runic inscriptions following principles delineated for heteroglossic language use in modern multilingual speech communities. In contrast to previous theoretical accounts of multilingualism in writing, the "heterographic" approach adds the important feature that contact in written language concerns not only parallel and mixed use of more than one language and writing system in a text, but also that semiotic resources from other levels of written language, such as graphetic (or typographic) features and spelling practices, can be "selected" by biscriptal users to produce meaning in mixed writing.

\section{Bibliography}

Aldrin, Emilia. 2016. "Names and Identity." In The Oxford Handbook of Names and Naming, ed. Carole Hough, 382-94. Oxford Handbooks in Linguistics. Oxford. Androutsopoulos, Jannis. 2000. "Non-standard Spellings in Media Texts: The Case of German Fanzines.” Journal of Sociolinguistics 4: 514-33.

—. 2006. "Introduction: Sociolinguistics and Computer-mediated Communication." fournal of Sociolinguistics 10: 419-38.

Angermeyer, Philipp Sebastian. 2012. "Bilingualism Meets Digraphia: Script Alternation and Hybridity in Russian-American Writing and Beyond." In Language Mixing and Code-switching in Writing Approaches to Mixed-language Written Discourse, ed. Mark Sebba, 255-72. Routledge Critical Studies in Multilingualism, 2. New York.

Arcamone, Maria Giovanna. 1980. "Antroponimia altomedievale nelle iscrizioni murali.” In Il Santuario di S. Michele sul Gargano dal VI al IX secolo: Contributo alla storia della Langobardia meridionale: Atti del Convegno tenuto a Monte Sant' Angelo il 9-10 dicembre 1978, ed. Carlo Carletti and Giorgio Otranto, 255-318. Vetera Christianorum: Scavi e ricerche, 2. Bari.

—. 1981. "Le iscrizioni runiche di Monte Sant'Angelo." Vetera Christianorum 18: 157-71. 
— . 1992. "Una nuova iscrizione runica da Monte Sant'Angelo." Vetera Christianorum 29: 405-10.

—. 2007. "Iscrizioni runiche in Italia." In I Germani e la scrittura: Atti del XXXIII Convegno dell'Associazione Italiana di Filologia Germanica (Pescara 7-9 giugno 2006), ed. Elisabetta Fazzini and Eleonora Cianci, 127-50. Alessandria.

Bammesberger, Alfred. 2010. "A Note on the Whitby Comb Runic Inscription." Notes and Queries 57.3: 292-95.

Barnes, Michael P. 2012. Runes, a Handbook. Woodbridge.

Blackledge, Adrian, Angela Creese, and Jaspreet Kaur Takhi. 2013. "Beyond Multilingualism: Heteroglossia in Practice.” In The Multilingual Turn: Implications for SLA, TESOL and Bilingual Education, ed. Stephen May, 191-215. New York.

Blommaert, Jan, and Ben Rampton. 2011. "Language and Superdiversity." Diversities 13: 1-22.

Bunčič, Daniel, Sandra L. Lippert, and Achim Rabus, eds. 2016. Biscriptality: A Sociolinguistic Typology. Akademiekonferenzen, 24. Heidelberg.

Carletti, Carlo. 1980. "Iscrizioni murali." In Il Santuario di S. Michele sul Gargano dal VI al IX secolo: Contributo alla storia della Langobardia meridionale: Atti del Convegno tenuto a Monte Sant'Angelo il 9-10 dicembre 1978, ed. Carlo Carletti and Giorgio Otranto, 7-180. Vetera Christianorum: Scavi e ricerche, 2. Bari.

- 1984-85. "I graffiti sull'affresco di S. Luca nel cimitero di Commodilla: Addenda et corrigenda." Atti della Pontificia Accademia Romana di Archeologia: Rendiconti 57: 129-43.

— . 2002. "Scrivere i santi: epigrafia del pellegrinaggio a Roma nei secoli VIIIX.” In Roma fra Oriente e Occidente, 1: 323-60. Settimane di studio del Centro italiano di studi sull'alto medioevo, 49. Spoleto.

— . 2004. "Iscrizioni runiche peninsulari: A proposito di un nuovo ritrovamento urbano." Atti della Pontificia Accademia Romana di Archeologia: Rendiconti 76: $525-42$.

Coulmas, Florian. 2013. Sociolinguistics: The Study of Speakers' Choices. 2nd ed. Cambridge.

Derolez, René. 1990. "Runic Literacy among the Anglo-Saxons." In Britain 400600: Language and History, ed. Alfred Bammesberger and Alfred Wollmann, 397-436. Anglistische Forschungen, 205. Heidelberg.

Derolez, René, and Ute Schwab. 1983. "The Runic Inscriptions of Monte S. Angelo (Gargano).” Mededelingen van de Koninklijke Academie voor Wetenschappen, Letteren en Schone Kunsten van België, Academiae Analecta: Klasse der Letteren 45: 95-130.

— . 1994. "More Runes at Monte Sant'Angelo." Nytt om runer 9: 18-19.

Fell, Christine. 1994. "Anglo-Saxon England: A Three-Script Community?" In Proceedings of the Third International Symposium on Runes and Runic Inscriptions, Grindaheim, Norway, 8-12 August 1990, ed. James E. Knirk, 119-38. Runrön, 9. Uppsala. 
Foxhall Forbes, Helen. 2019. "Writing on the Wall: Anglo-Saxons at Monte Sant'Angelo sul Gargano (Puglia) and the Spiritual and Social Significance of Graffiti.” Journal of Late Antiquity 12: 169-210.

Handley, Mark A. 2013. "Saxons, Britons and Scots: Pilgrims, Travellers and Exiles on the Continent." In Early Medieval Art and Archaeology in the Northern World, ed. Andrew Reynolds and Leslie Webster, 743-80. The Northern World: North Europe and the Baltic c. 400-1700 AD: Peoples, Economies and Cultures, 58. Leiden.

King, Robert D. 1998. Nehru and the Language Politics of India. Oxford India Paperbacks. Delhi.

Insley, John. 2008. "Anglo-Saxons in Rome: The Evidence of the Names." In Nomen et Fraternitas, ed. Uwe Ludwig and Thomas Schilp, 107-13. Reallexikon der Germanischen Altertumskunde, Ergänzungsbände, 62. Berlin and New York.

Izzi, Luisa. 2014. "Anglo-Saxons Underground: Early Medieval Graffiti in the Catacombs of Rome." In England and Rome in the Early Middle Ages: Pilgrimage, Art, and Politics, ed. Francesca Tinti, 141-77. Studies in the Early Middle Ages, 40. Turnhout.

MacLeod, Mindy. 2002. Bind-runes: An Investigation of Ligatures in Runic Epigraphy. Runrön, 15. Uppsala.

Mastrelli, Carlo Alberto. 1980. "Le iscrizioni runiche." In Il Santuario di S. Michele sul Gargano dal VI al IX secolo: Contributo alla storia della Langobardia meridionale: Atti del Convegno tenuto a Monte Sant'Angelo il 9-10 dicembre 1978, ed. Carlo Carletti and Giorgio Otranto, 319-32. Vetera Christianorum: Scavi e ricerche, 2. Bari.

Okasha, Elisabeth. 1971. Hand-List of Anglo-Saxon Non-Runic Inscriptions. Cambridge.

- 2018. "Roman Script and Runes in Anglo-Saxon Inscriptions: An Intermedial Usage?" In Epigraphy in an Intermedial Context, ed. Alessia Bauer, Elise Kleivane, and Terje Spurkland, 31-42. Dublin.

Orton, Peter. 2014. Writing in a Speaking World: The Pragmatics of Literacy in Anglo-Saxon Inscriptions and Old English Poetry. Medieval and Renaissance Texts and Studies, 455. Tempe, Arizona.

Page, Raymond Ian. 1962. "The Use of Double Runes in Old English Inscriptions." Journal of English and Germanic Philology 61: 897-907.

—. 1994. "English Runes Imported into the Continent." In Runische Schriftkultur in kontinental-skandinavischer und -angelsächsischer Wechselbeziehung, ed. Klaus Düwel, Sean Nowak, and Hannelore Neumann, 176-94. Reallexikon der Germanischen Altertumskunde, Ergänzungsbände, 10. Berlin and New York.

—. 1999. An Introduction to English Runes. 2nd ed. Woodbridge.

—. 2003. "Runenmünzen, § 1. England." In Reallexikon der germanischen Altertumskunde, founded by Johannes Hoops, ed. Heinrich Beck, Thomas Andersson, and Rosemarie Müller, 22: 546-52. 2nd ed. Berlin. 
Parsons, David N. 1999. Recasting the Runes: The Reform of the Anglo-Saxon Futhorc. Runrön, 14. Uppsala.

RuneS-DB = Database of the RuneS research project, i.e. "Runic writing in the Germanic languages”, Akademie der Wissenschaften zu Göttingen. www. runesdb.eu

Searle, William George. 1897. Onomasticon Anglo-Saxonicum: A List of AngloSaxon Proper Names from the Time of Beda to that of King John. Cambridge.

Sebba, Mark. 2009. "Sociolinguistic Approaches to Writing Systems Research." Writing Systems Research 1: 35-49.

— . 2012. "Multilingualism in Written Discourse: An Approach to the Analysis of Multilingual Texts." International fournal of Bilingualism 17: 97-118.

Seiler, Annina. 2014. The Scripting of the Germanic Languages: A Comparative Study of "Spelling Difficulties" in Old English, Old High German and Old Saxon. Medienwandel-Medienwechsel-Medienwissen, 30. Zürich.

Sinisi, Lucia. 2014. "Beyond Rome: The Cult of the Archangel Michael and the Pilgrimage to Apulia." In England and Rome in the Early Middle Ages: Pilgrimage, Art, and Politics, ed. Francesca Tinti, 43-68. Studies in the Early Middle Ages, 40. Turnhout.

Trotta, Marco. 2012. Il Santuario di San Michele sul Gargano dal tardoantico all' altomedioevo. Bari.

Waxenberger, Gaby. 2011. "The Old-English Runic Inscription of the Whitby Comb and Modern Technology." Amsterdamer Beiträge zur älteren Germanistik 67: 69-77.

— . 2016. "Graphemes: (Re)construction and Interpretation." In Variation within and among Writing Systems, ed. Paola Cotticelli-Kurras and Alfredo Rizza, 35370. LautSchriftSprache, 1. Wiesbaden.

Webb, Diana. 1999. Pilgrims and Pilgrimage in the Medieval West. International Library of Historical Studies, 12. London etc. 